\title{
A third medieval bridge on Lake Lednica, Greater Poland
}

\author{
Třetí středověký most na Lednickém jezeře
}

Andrzej Pydyn - Mateusz Popek

\begin{abstract}
Lake Lednica, Greater Poland, is one of Poland's most important and longest-studied underwater archaeological sites. The residential centre established on an island was one of the central points in the state of the first Piasts. Previous research located two bridges to the island and discovered the largest collection of early medieval military objects in Central Europe in the lake. In the 2017 season, a third bridge was discovered on Lake Lednica leading to the small island called Ledniczka on which the layers of an early medieval settlement and clear remnants of a motte-type medieval structure are found. Three seasons of research on relics of the crossing suggest that it may have functioned in two periods: in the tenth century and at the turn of the fourteenth century. During the research, a number of military items, pottery, objects made of organic materials and fishing tools were found.
\end{abstract}

bridge - Middle Ages - Lake Lednica - underwater archaeology

Lednické jezero ve Velkopolsku patří k nejdůležitějším a nejdéle studovaným lokalitám podvodní archeologie ve střední Evropě. Rezidenční centrum zř́zené na zdejším Lednickém ostrově bylo jedním z hlavních míst prvních Piastovcủ. Předchozí výzkum odhalil dva mosty spojujicí ostrov s pevninou a největši soubor militárii ze dna středoevropského jezera. V roce 2017 byl identifikován další most, tentokrát zpř́stupňující ostrůvek zvaný Ledniczka. Dalši výzkum ukázal, že most pravděpodobně fungoval ve dvou periodách: v 10. století a na prèelomu 13. a 14. století. Přinesl také početný soubor militárií, keramiky, rybárského náčiní a výrobků z organických materiáli̊. Na ostrůvku byly dokumentovány raně středověké situace a opevnění typu motte.

most - středověk - Lednické jezero - podvodní archeologie

\section{Introduction}

Ostrów Lednicki, situated on Lake Lednica, along with an entire early-medieval settlement complex, is one of the most important archaeological sites in Poland. The site's importance is confirmed by its 1994 listing as a Historical Monument [Pomnik Historii], which is one of Poland's highest forms of cultural heritage protection. The first research on the site appeared in the mid-nineteenth century, but further research and analyses are being carried out to this day (Górecki 2016, 30). It is also undoubtedly one of the most important underwater archaeological sites in Poland. Two bridge crossings to Ostrów Lednicki were initially located in the early 1960 s by recreational divers.

Since 1982, underwater archaeological sites of Lake Lednica have been continuously studied by a team from Nicolaus Copernicus University in Torun, currently represented by the Centre for Underwater Archaeology of Nicolaus Copernicus University (Kola 2000, 12; Kola et al. 2016, 107). These nearly forty years of underwater research activity have resulted in a thorough analysis of the two early medieval bridges (Kurnatowska ed. 2000; KolaWilke eds. 2014; Kola et al. 2016), seven logboats (Ossowski 2014), the largest collection of early medieval militaria in Central Europe (Kurnatowska ed. 2000; Kola - Wilke eds. 
2014; Sankiewicz 2013, 26) and an extensive collection of other archaeological artefacts. It should also be stressed that, every year, research in the Lake Lednica area brings new and interesting discoveries. The most valuable is the discovery of a third medieval bridge that led to the island of Ledniczka, which is located south-west of Ostrów (Pydyn et al. 2018).

\section{The archaeology of Ostrów Lednicki}

There are several dozen archaeological sites around Lake Lednica (fig. 1). However, the most important is a residential and religious centre on Ostrów Island in the central part of the lake (Ostrów Lednicki). The occupation layers contained cultural items dating back to the Stone Age, but settlement on the island experienced its greatest development in the Middle Ages, at the turn of the eleventh century in particular (Wyrwa 2016, 303). At the end of the ninth century or the beginning of the tenth century, a fortified settlement was erected in the southern part of the island, and its defensive fortifications were then reworked and/or expanded three times (Górecki-Lastowiecki 2016, 59-72). A palace was built inside the extended stronghold in the second half of the tenth century. This endeavour is directly associated with Mieszko I, the first historically known ruler of Poland, and it was probably built at the same time as the bridges that have been known about for several decades (fig. 2). Another important masonry building inside the defensive complex is known as the "second church". It was also erected in the 960s and ceased to function by the end of the eleventh century (Wrzesinski - Kara 2016, 193). Outside the stronghold, both on the island as well as on the shore at the lake settlements, evidence of different crafts activities has been found. This includes a place for the gathering and slaughtering of animals. The existence of smelting, blacksmithing, horn-working and goldsmith workshops was also determined (Banaszak - Tabaka 2016, 290-297). Scandinavian imports (Duczko 2016) and objects from eastern cultural circles (Kowalczyk et al. 2019) testify to the importance of Ostrów Lednicki.

The remains of two bridges (fig. 2) discovered at the end of the 1950s and the beginning of the 1960s were called the Poznań bridge, leading westwards, and the Gniezno bridge, leading eastwards (Kola et al. 2016, 107).

The Gniezno bridge, from the central part of the island to the eastern shore of the lake, was $187 \mathrm{~m}$ long, while its reconstructed width is about $5 \mathrm{~m}$. It was erected using a beam construction and rebuilt several times. Numerous dendrochronological analyses determined that the bridge was erected in the 960s, and then rebuilt or repaired five times in the years: 976-978, 979-981, 982-1006, 1007-1017 and in 1032 (Krapiec 2000; Wilke 2000; Kola et al. 2016, 111-117). The discovery of the above-water structural parts of the bridge allowed its appearance to be reconstructed (fig. 3). After piles were driven in, they were combined into bundles, which were joined with a yoke beam across the axis of the bridge. This created one pillar of the crossing. The pillars were connected with each other by placing joist beams on the yoke beams to form the bridge spans and its load-bearing structure. The last element consisted of transverse boards, or laths, that constituted the roadway (Krapiec 2000, 49-56; Wilke 2000, 57-72; Kola et al. 2016, 113-116). Unfortunately, the data that has been collected does not yet allow for the existence of barriers on the bridge to be reliably confirmed or reconstructed. During the research, a huge number of organic artefacts was also found, allowing conclusions to be drawn regarding many aspects of the lives of the early medieval inhabitants of Ostrów Lednicki: from agriculture (Szulta 2000), through everyday life (Grupa 2000), fashion (Drażkowska 2000) and craftsmanship (Mateuszewska-Kola 2000), to the art of war (Gtosek - Kirpičnikov 2000; Tokarski 2000). 


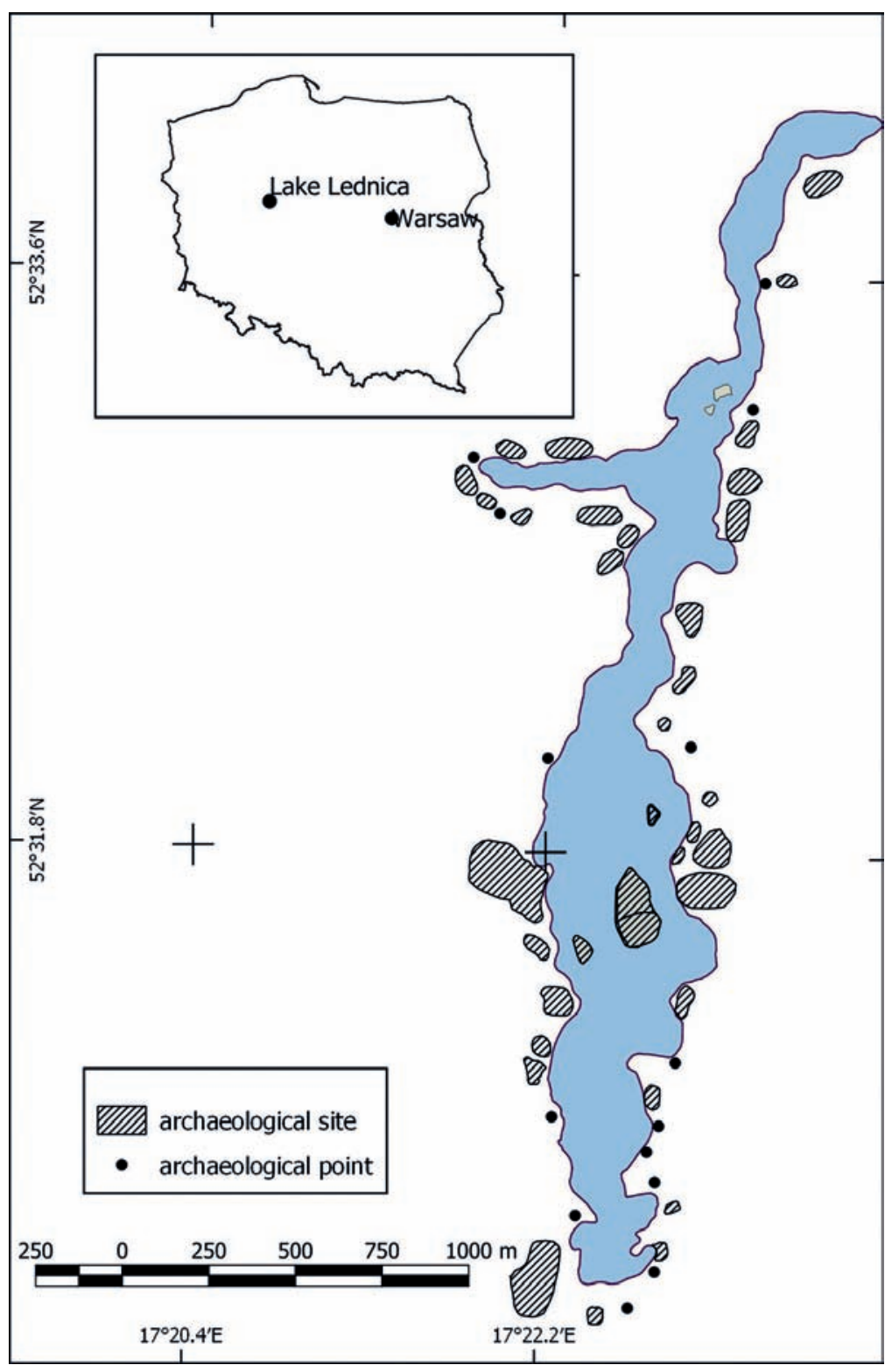

Fig. 1. Archaeological sites near Lake Lednica (by

M. Popek). 


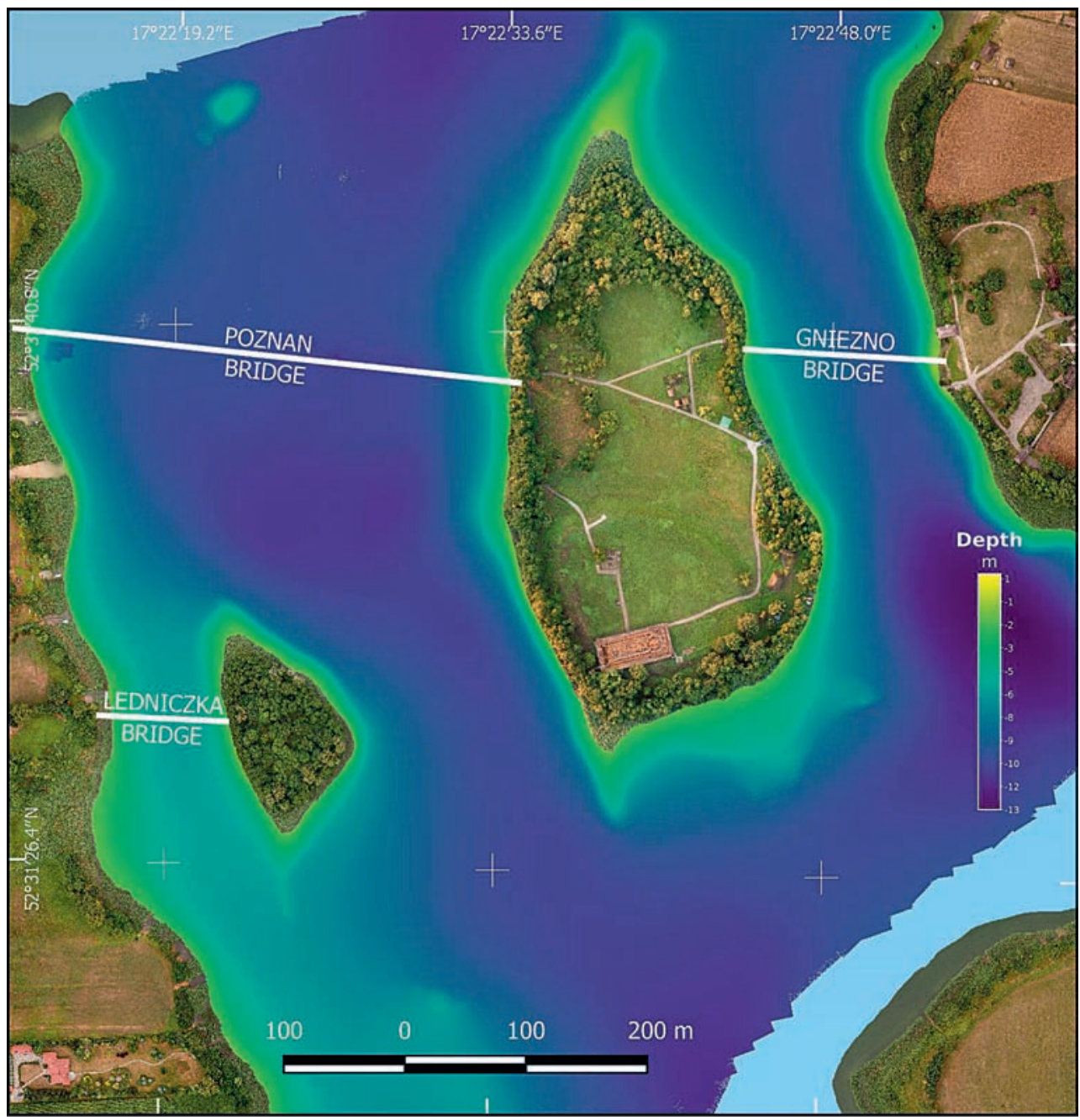

Fig. 2. Bridges of Lake Lednica (by M. Popek, P. Stencel).

diameter. Trees aged 21-60 years were mainly used, accounting for 71.5\% of all analysed piles (Radka 2014a, 41-68; Kola et al. 2016, 122). Numerous artefacts have been found on the Poznań bridge, as with the Gniezno bridge, allowing inferences to be made about the life of the early medieval community of Ostrów Lednicki (Kola - Wilke eds. 2014).

During research on the bridges, as well as during surveys around the lake, a huge quantity of early medieval military equipment was found. Apart from the remains of the bridges, these objects were mostly concentrated on the north-west side of the island (Wilke 2006; Kola et al. 2016, 127). Items of arms and armour include: 141 axes (Sankiewicz 2013, 28); 48 spear points, including three fully preserved spears (Sankiewicz 2018, 28); seven swords (Sankiewicz 2011, 13); a conical helmet; and chain mail. However, besides the militaria, many other items - especially sickles - were found around the island. 
In the waters of Lake Lednica, a significant number of logboats have also been found. Of as many as seven specimens found in the lake, three are from the Early Middle Ages. Two from this period have been extracted, while one remains in situ. They were made of wood such as oak, linden and poplar. All the specimens are of an exceptional length for dugouts, ranging around $10 \mathrm{~m}$. They may have served transport, military or prestige functions (Ossowski 1999; 2014; Radka 2017).

\section{The archaeology of Ledniczka Island}

In terms of the latest discoveries on Lake Lednica, of particular importance is the site on the island of Ledniczka, also known as Kuchnia Polska [Polish Cuisine] or Kucharka [Cook] (fig. 3). There is a motte-type structure on this island, rising $6 \mathrm{~m}$ above ground level. Its flat top has a diameter of $20 \mathrm{~m}$. To its north-west is a semi-circular earthen embankment $1.80 \mathrm{~m}$ high and $20 \mathrm{~m}$ wide. Between the embankment and the stronghold is a depression that may be the remains of a moat (Górecki et al. 1996). Archaeological studies on the top of the motte have revealed the remains of three buildings. Two had the lower part of their walls made of stones, while the third building is a half-dugout (Górecki et al. 1996, 206-209). A fairly diverse collection of artefacts was also found in the occupation layers, including blacksmith tools, household equipment, clothing, and military items (Górecki et al. 1996, 210). Of the militaria, pieces of small arms in particular, such as bolt heads, correspond to finds from the remains of the bridge leading to the island. The chronology of this site was determined - based on the excavated archaeological materials and the shape of the motte - as being fourteenth-century (Górecki et al. 1996, 234-235). Most likely the earthworks carried out here at that time must have caused significant damage to the previous layers. The medieval motte-type structure on Ledniczka Island should be associated with the functioning here of the Ostrów castellany that was either founded on the island in the thirteenth century or transferred here from neighbouring Ostrów Lednicki at the end of that century (Wasilewski 1967, 554; Leśny 1976, 19; Górecki et al. 1996, 239). Comparing the written sources against the archaeological research suggests that the end of the occupation of the island falls between 1471 and 1521 (Górecki et al. 1996, 239). Another interpretation is that this settlement was not a castellany, but rather the seat of the local noble Latalski family (Górecki et al. 1996, 240).

\section{The bridge to Ledniczka Island}

Information on the potential existence of a bridge to Ledniczka Island comes from the end of the nineteenth century: one of the first publications on Lake Lednica reads: In the end, it seems that these two islands were once connected to each other, and again to the mainland on each side, both towards Gniezno and towards Poznan, by a wooden bridge whose remains lie at the bottom of the lake. From time to time in these areas, fishing nets catch on piles protruding under the water. [...] A present-day tenant of the village of Dziekanowice had, no longer ago than on the eve of our last stay on the island, amassed fourteen such piles. (Sokołowski 1876, 125-126). The author is probably describing as many as four bridges: two leading from Ostrów Lednicki to the shore, a third between the main 

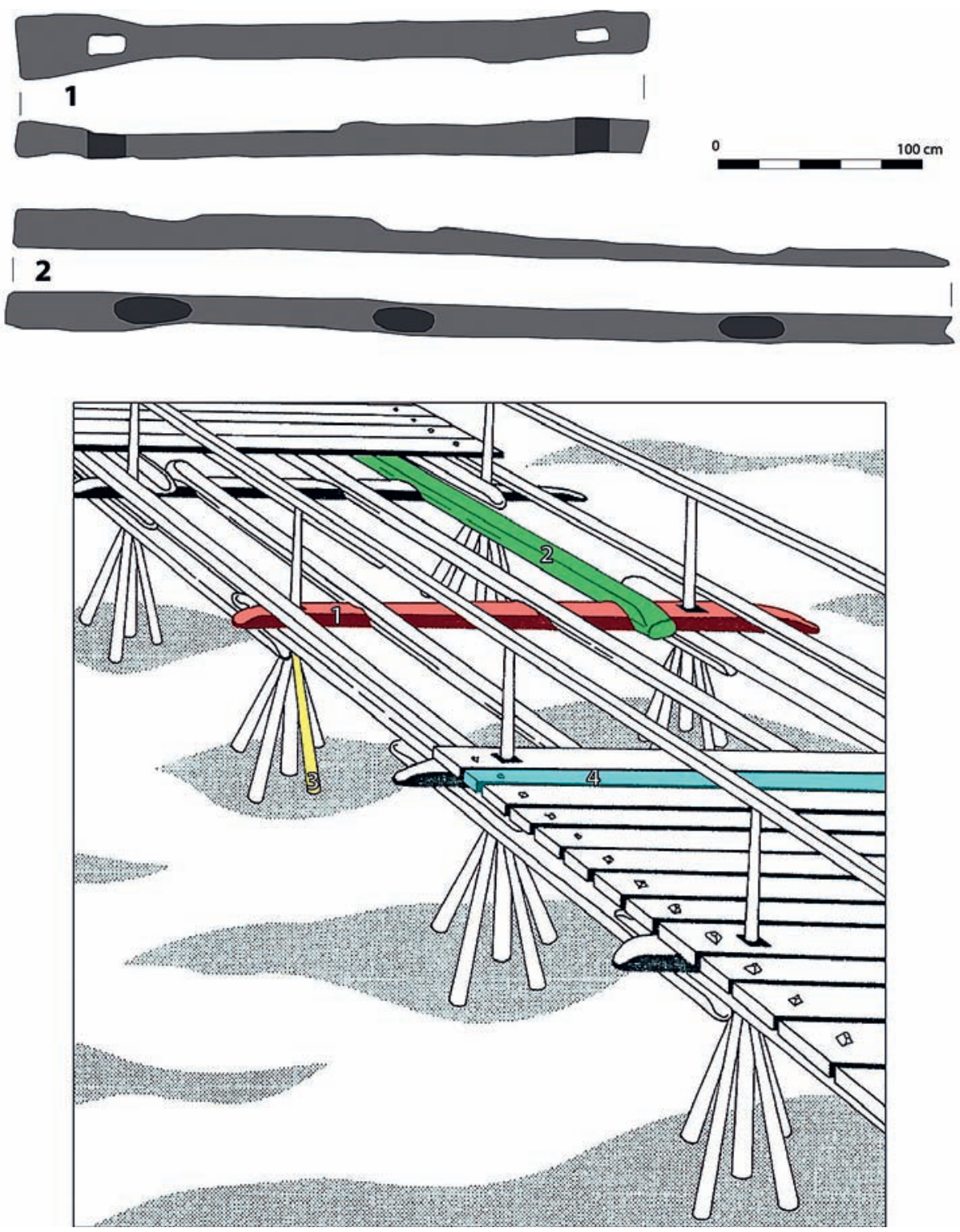

Fig. 3. Model of the construction of the medieval bridge: red (1) - yoke beam, green (2) - joist/mudsill beam, yellow (3) - pile, blue (4) - lath/board (based on Kola - Wilke 2000).

island and Ledniczka, and a fourth from Ledniczka to the land. It is difficult to clearly assess whether this nineteenth-century account was based on the collective memory of local residents or was instead the writer's hypothesis. The information about fourteen piles excavated from the lake the day before the arrival of the author of this text remains undisputed. Unfortunately, we do not know from which of the bridges that functioned here in the past the piles in question were obtained. In the 1980s, unconfirmed information from 


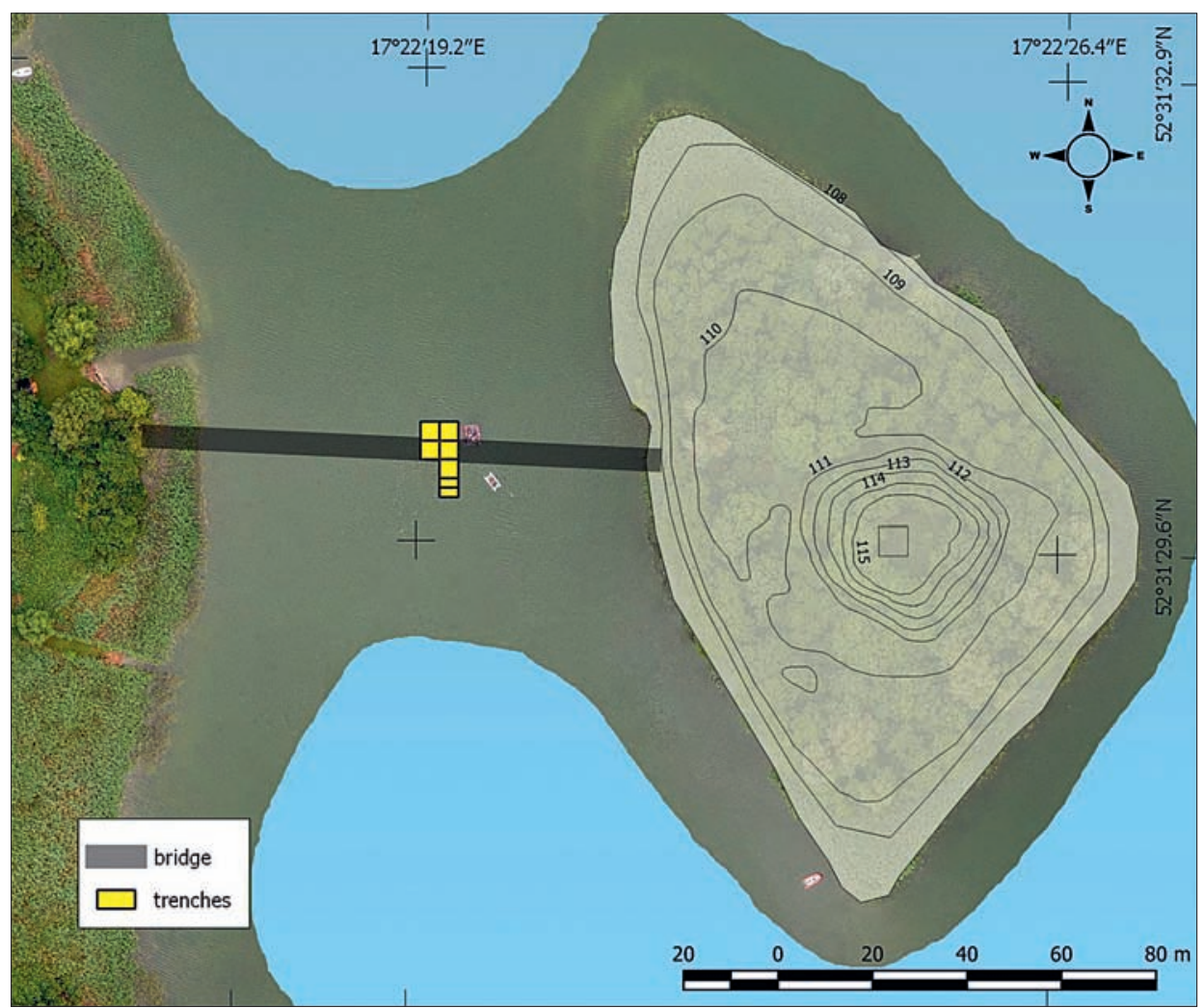

Fig. 4. Axis of bridge to Ledniczka Island and range of excavated area (by M. Popek, P. Stencel).

a local sculptor living in the village of Rybitwy appeared to the effect that, in the past, wood of the so-called black oak had been extracted for him from around Ledniczka Island, and he had used it for carving (Pydyn et al. 2018, 186).

It was this information, as well as the notes from the nineteenth century, that inspired the Department of Underwater Archaeology of the Nicolaus Copernicus University in Torun to attempt to find the bridge crossing to Ledniczka in the 1980s and 1990s. Unfortunately, multiple dives around the island brought no success, and archaeologists focused their interest on the famous bridge crossings of Ostrów Lednicki (Kola - Wilke 1983, 3).

The situation changed thanks to the project: Kolebka Piastów: archeologiczne prospekcje podwodne w rejonie Jeziora Lednickiego [The Cradle of the Piasts: Archaeological Underwater Prospections in the Area of Lake Lednica], supported by the Ministry of Culture and National Heritage. This project aimed to comprehensively identify the archaeological resources of Lake Lednica. During the analysis of bathymetric maps, potential anomalies were identified between Ledniczka island and the mainland. The conducted surveys located the structural elements of a bridge (Pydyn et al. 2018, 182). In 2017, as part of the aforementioned project, preliminary documentation of the relics of the bridge was also compiled, and its systematic exploration and documentation began in the 2018 season (Pydyn 2018; Pydyn - Popek 2019). 


\begin{tabular}{|c|c|c|c|c|c|c|c|}
\hline $\begin{array}{c}\text { Construction } \\
\text { element }\end{array}$ & Task No & Sample $\mathrm{N}^{\circ}$ & $\begin{array}{c}\text { Conventional } \\
\text { date }\end{array}$ & ${ }^{14} \mathrm{C}$ date (cal.) & $\begin{array}{c}\text { Dendro-chrono- } \\
\text { logical date }\end{array}$ & $\begin{array}{c}\text { Diameter } \\
\mathrm{Cm}\end{array}$ & $\begin{array}{l}\text { Wood } \\
\text { species }\end{array}$ \\
\hline Pile 1 & $12973 / 17$ & Poz-96677 & $1085 \pm 30 \mathrm{BP}$ & $\begin{array}{c}\text { 95.4\% probability } \\
\text { 894AD (30.5\%) 932AD } \\
\text { 937AD (64.9\%) 1016AD }\end{array}$ & --- & 13.8 & oak \\
\hline Pile 2 & $14226 / 18$ & Poz-107513 & $1125 \pm 30 \mathrm{BP}$ & $\begin{array}{c}\text { 95.4\% probability } \\
\text { 777AD }(2.4 \%) \text { 791AD } \\
\text { 807AD }(1.2 \%) \text { 819AD } \\
\text { 825AD }(2.1 \%) 842 \mathrm{AD} \\
\text { 862AD }(89.7 \%) 991 \mathrm{AD}\end{array}$ & ----- & 24.1 & ---- \\
\hline Pile 3 & & & & --- & ---- & 17.0 & elm \\
\hline Pile 4 & $13961 / 18$ & Poz-105039 & $1135 \pm 30 \mathrm{BP}$ & $\begin{array}{c}\text { 95.4\% probability } \\
\text { 777AD (4.3\%) 792AD } \\
\text { 803AD (8.0\%) 844AD } \\
\text { 857AD }(83.0 \%) 986 \mathrm{AD}\end{array}$ & ---- & 14.6 & oak \\
\hline Pile 5 & $13961 / 18$ & Poz-105040 & $1110 \pm 30 \mathrm{BP}$ & $\begin{array}{c}\text { 95.4\% probability } \\
\text { 879AD (95.4\%) 1013AD }\end{array}$ & ---- & 18.5 & oak \\
\hline Pile 6 & $14226 / 18$ & Poz-107512 & $1120 \pm 30 \mathrm{BP}$ & $\begin{array}{c}\text { 95.4\% probability } \\
\text { 778AD (1.7\%) 790AD } \\
\text { 809AD (0.5\%) 815AD } \\
\text { 826AD }(1.4 \%) \text { 841AD } \\
\text { 863AD }(91.8 \%) \text { 995AD }\end{array}$ & ---- & 21.2 & ---- \\
\hline Pile 7 & $14226 / 18$ & Poz-107511 & $745 \pm 30 \mathrm{BP}$ & $\begin{array}{c}\text { 95.4\% probability } \\
\text { 1223AD (95.4\%) 1289AD }\end{array}$ & ---- & 25.6 & --- \\
\hline Pile 8 & & & & --- & 913/914 AD & 19.6 & oak \\
\hline Pile 9 & & & & ---- & --- & 19.5 & elm \\
\hline Pile 10 & & & & ---- & ---- & 17.6 & oak \\
\hline Pile 11 & & & & --- & --- & 17.0 & oak \\
\hline Beam & & & & ---- & $1302 \mathrm{AD}$ & ---- & oak \\
\hline
\end{tabular}

Tab. 1. List of construction elements with dating, diameter and species of the wood from which they were made (Goslar 2017; 2018a; 2018b; Ważny 2017; 2019).

\section{Analysis of construction}

During two years of works, $96 \mathrm{~m}^{2}$ of bridge remains were excavated, which is only $6 \%$ of the area in which the remains of the bridge might be found (fig. 4). The research excavations were conducted in the central part of the crossing, precisely where the bathymetric anomalies were located. An important observation was that no bridge remains were found around the location of the bridgehead on the island side. They were probably destroyed by unusual sedimentation and post-depositional processes that occur around Ledniczka Island.

The underwater part of the bridge can be reconstructed on the basis of the arrangement of piles. In the case of the tested object, 11 vertical structural elements have so far been documented. All piles underwent dendrochronological analysis. Unfortunately, only one, along with one horizontal structural element, provided specific dates. This dating was particularly hampered by the small number of annual growth rings in many collected samples and by the elements having been produced using tree species other than oak. Nevertheless, the obtained dates are extremely interesting and allow for an initial chronological interpretation of the structure. The dated sample from the pile was well preserved: it had 130 annual growth rings and a sapwood layer. This made it possible to date the felling of the tree used to make the pile to the autumn of 913 or the winter of 913/914 (Ważny 2019). The date obtained for the sample taken from the horizontal element is much younger. The analysed element did not have a sapwood layer, but it can be stated that it came from a tree 


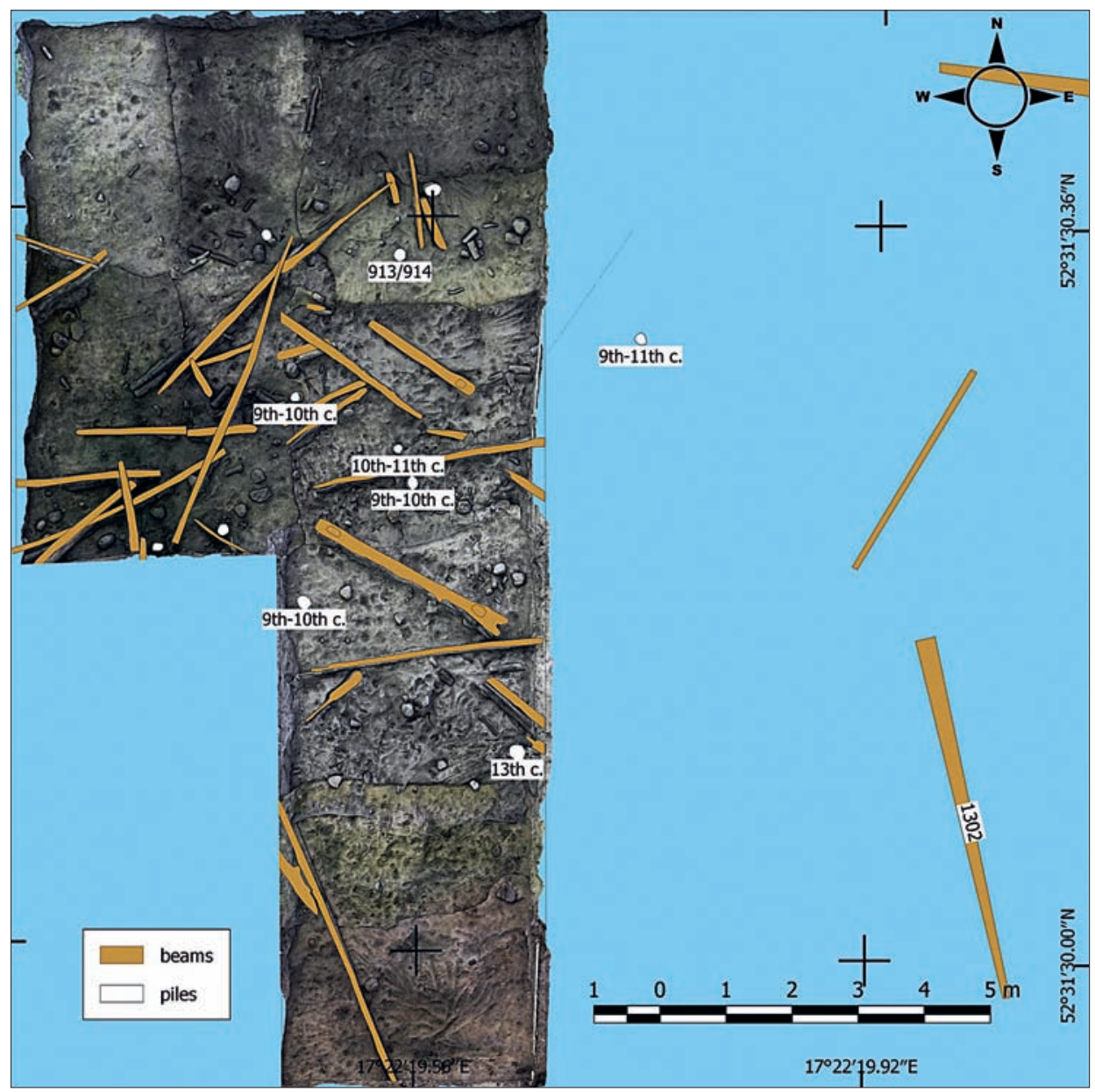

Fig. 5. Bridge construction elements with radiocarbon and dendrochronological dating results, with orthophotography of excavated area (by M. Popek, P. Stencel).

felled after 1293 - most likely in 1302 (Ważny 2017). A valuable supplement to the dendrochronological dates is provided by calibrated radiocarbon datings from tests on six piles by the Poznań Radiocarbon Laboratory. Slices of wood for radiocarbon analysis were cut from six piles. Each sample contained a layer of cambium. Dating was performed at Poznań Radiocarbon Laboratory on the outer part of the slices in order to obtain a date closest to that of the felling of the tree (Goslar 2017; 2018a; 2018b).

The dendrochronological and radiocarbon dates complement each other, suggesting that the crossing may have functioned in two periods. The first is dated to the tenth century, the second to the turn of the fourteenth century. However, in order to confirm this thesis, a larger series of dendrochronological datings should be made (fig. 5).

Upon analysis of the remains of the bridge, it can be concluded that it was about $100 \mathrm{~m}$ long and ran on an east-west axis (Pydyn et al. 2018, 187). It was built at the narrowest 


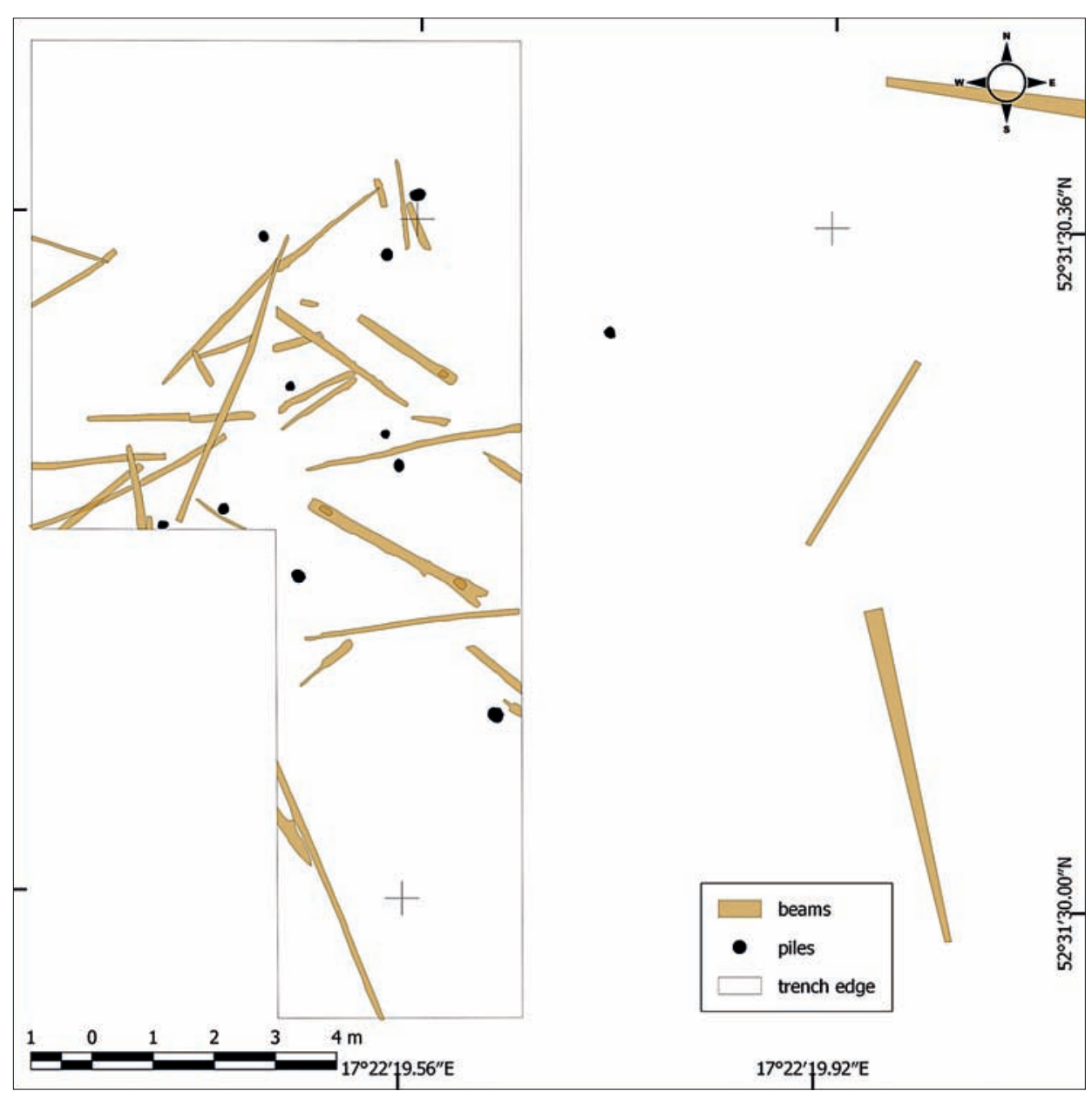

Fig. 6. Planigraphy of bridge construction elements (by M. Popek).

point between the island and the mainland. The vertical relics of the bridge are spread over a width of about $6.5 \mathrm{~m}$, which may suggest the width of the crossing. This means that it was slightly wider than the bridges erected by Mieszko I, which were most probably about 5 m wide (Wilke 2000; 2014; Kola et al. 2016, 111-121). However, any final reconstruction of the bridge to Ledniczka should be deferred until more structural elements are uncovered.

One way to reconstruct the width of the bridge is to determine the distance between the holes in the yoke beams (fig. 3). This is based on the principles of early medieval Slavic bridge construction, which suggest that the yoke beams were placed on piles or a group of two or three piles to form pillars (Wilke 2000). During the research on the bridge to Ledniczka, two yoke beams were found, including a complete one and another with only one yoke hole (fig. 6). The distance between the yoke holes on the complete beam was $2.5 \mathrm{~m}$. This seems too small, both in terms of the width of the bridge and the length of the 
span, because in such a case the 100-m bridge would have had to consist of as many as 40 spans. It is likely that this was a single, atypical construction element. Early medieval bridges were built using a beam technique or a much simpler technique that used two or three piles in a pillar (Szulta 2008). The arrangement of piles on the Ledniczka bridge does not fit any of these types (fig. 6). Perhaps this is because there are still too few known relics, and future research will provide answers to these issues.

At the present stage of research, our knowledge about the crossing from the thirteenth to fourteenth century is also incomplete. Dendrochronological and radiocarbon dating confirmed the chronology of selected structural elements. These elements are located slightly south of the relics dated to the tenth century.

\section{The stratigraphy of the bridge}

Because medieval bridges were built mainly on lakes in which the bottom layers are well preserved and undisturbed, it is often possible to recognise the layers associated with the bridge's function, and even those related to its construction phase. The latter are characterised by the large amounts of wood shavings produced during construction. Such layers were noted on the Poznań and Gniezno bridges (Kola - Wilke 1989, 87-89).

The multi-phase nature of the crossing to Ledniczka affects the appearance of its stratigraphic layers. We can distinguish between two distinct cultural layers related to the construction and the use of bridges, and two separate layers of grey lake sand, which are most likely associated with periods when the bridges were defunct. The whole structure is covered with several dozen centimetres of biogenic, natural bottom sediments.

\section{Artefacts}

Anaerobic conditions in lake sediments mean that artefacts made of various types of materials are often preserved. This was the case in the research on the remains of the bridge to the island of Ledniczka. Metal items - especially military ones - were documented here, as well as items made of organic materials such as wood and leather, of which objects related to fishing represent an interesting category (fig. 7).

Among the military finds, as many as five arrowheads, one bolt arrowhead, two axes, a pike and a spear were found (figs. 8 and 9). Two types of arrowheads can be distinguished in the collection: tips with a sleeve and tips with a shank (fig. 8). One specimen with a shank had a preserved shaft fragment (fig. 8: 7). The eight-sided shaft was affixed to the tip by a black substance - probably tar. All the specimens are quite delicate and approximately $5 \mathrm{~cm}$ long and 1-2 cm wide. Based on well-dated analogues from other sites, it is possible to cautiously determine that these items originate from between the twelfth century and the turn of the fifteenth century (Wachowski 1982, 179; Gedl 2002, 76-77; Abramek 2007, 5-6). Another issue is that doubts exist as to whether the heads should be identified as arrow- or boltheads. In fact, there were no differences in morphology between the two, with the main difference being mainly in their size and weight (Abramek 2007, 5). Therefore, based on these differentiators, it was concluded that most of the items in question were arrowheads. ${ }^{1}$

\footnotetext{
${ }^{1}$ We thank Piotr Dmochowski for his kind consultation.
} 


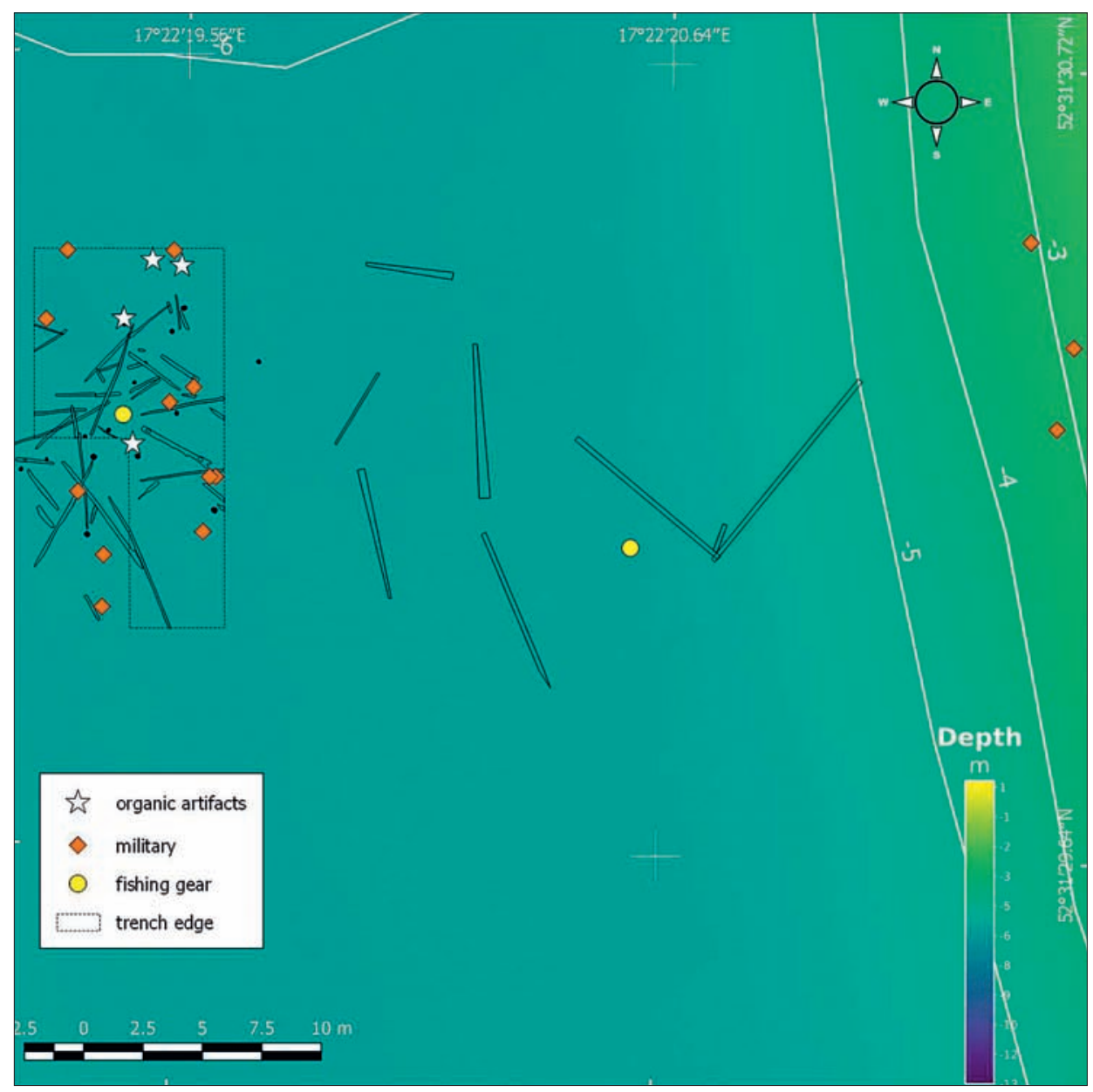

Fig. 7. Location of artefacts at the site of the bridge to Ledniczka Island (by M. Popek).

The boltheads were represented by two examples (fig. $8: 1-2)$. The first is a head with a total length $9.2 \mathrm{~cm}$ and width $1.4 \mathrm{~cm}$ (fig. $8: 1$ ). The sleeve length was $2.5 \mathrm{~cm}$ and the blade length was $5.2 \mathrm{~cm}$. A piece of shaft was preserved in the sleeve of the specimen in question. This specimen is of type I according to A. Nadolski's typology of bolts. These heads are dated broadly to between the twelfth and sixteenth centuries (Nadolski 1954, 65). The second bolthead is a square-profiled head $7.7 \mathrm{~cm}$ long and over $2 \mathrm{~cm}$ wide (fig. 8: 2). In the part where the shank should be found, the head was broken, so it is difficult to determine the size of the entire piece (Pydyn et al. 2018, 188). Based on the typology created by A. Nadolski, this specimen can be designated as type I, which is dated to the twelfth to sixteenth century. During the land-based research carried out on Ledniczka Island, 14 boltheads were documented, the dates of which were determined to be similar to the dates of those found in the water (Górecki et al. 1996, 229; Pydyn et al. 2018, 188). Also, during the underwater research on the Poznań bridge, one analogous example was identified (Popek 2014, 136). 

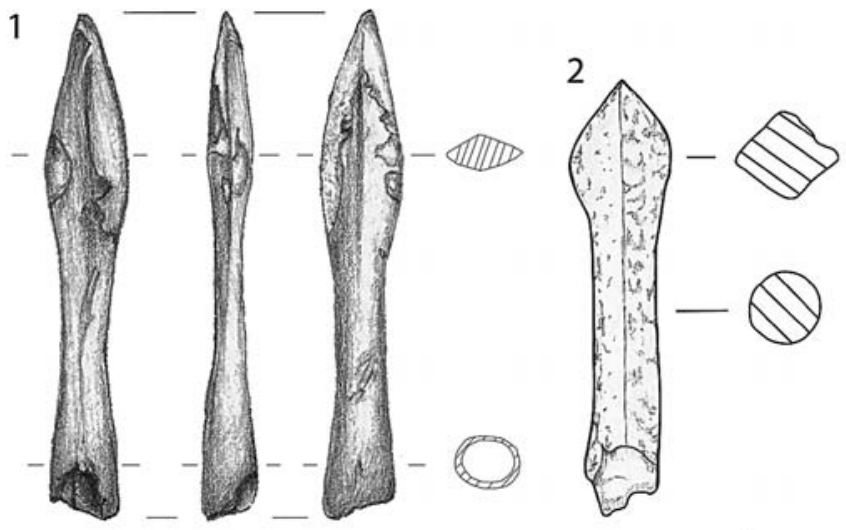

3
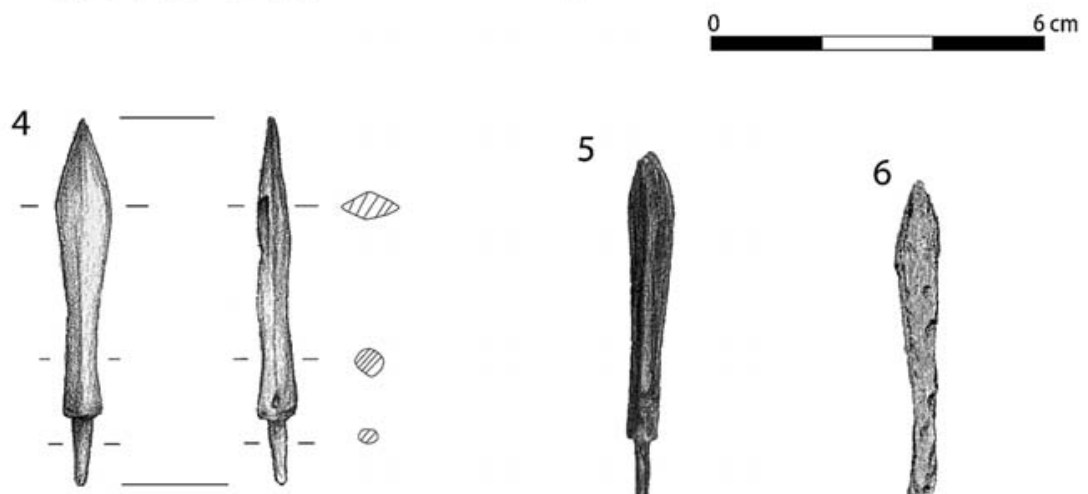

5

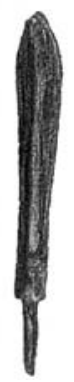

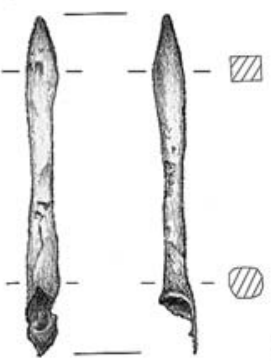

7
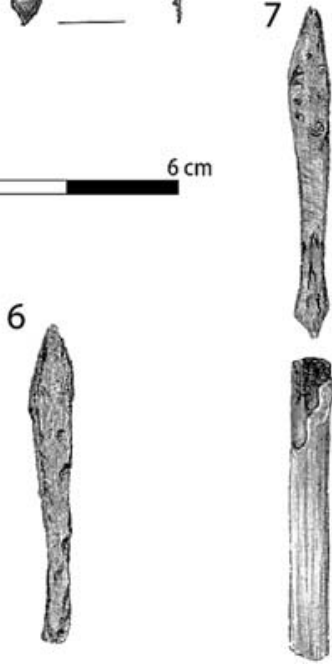

Fig. 8. Arrowheads and bolts (1, 3, 4 by N. Stawarz; 2 by A. Kulesz; 5, 6, 7 by K. Kociszewska).

Another category of military objects found on the relics of the bridge to the island of Ledniczka is iron axe heads. The first of the axes, with a preserved fragment of shaft, was $19.5 \mathrm{~cm}$ long and $3.48 \mathrm{~cm}$ wide at the base (fig. 9: 4). The blade of this specimen was $10.9 \mathrm{~cm}$ long. The shaft fragment tapered slightly toward the bottom, forming a gentle cone. The blade of this specimen was rounded, with a pronounced beard, and the toe was almost perpendicular to the head. Such a construction allows the item to be classified as type IX according to Głosek. These types of artefacts date to the thirteenth to fifteenth century and are regarded as household or carpentry items (Gtosek 1996, 40-42). The second iron axe specimen was not found during the excavations, but during the first surveys of the site in 2017. This axe had an asymmetrical, slightly arched blade $8.8 \mathrm{~cm}$ long and $0.5 \mathrm{~cm}$ thick (fig. 9: 3). The lower part of the beard was broken off. The eye took the form of a sleeve that was very elongated downwards; it was $12.9 \mathrm{~cm}$ long and $2.3 \mathrm{~cm}$ thick at its widest point. The item can be designated as type $\mathrm{X}$ according to Głosek and dated to the fourteenth to fifteenth century. These objects were most likely used for carpentry, as evidenced by iconographic representations (Głosek 1996, 43-45; Pydyn et al. 2018, 188).

The spearhead found in the first seasons of research is in very good condition (fig. 9: 2). It was $23 \mathrm{~cm}$ long, and the cross-section of the spearhead was diamond-shaped. A fragment of shaft was preserved in the sleeve. At its base, the sleeve formed a 2.9-cm-wide 
Fig. 9. Axes and spearhead from the bridge to Ledniczka Island (1, 3 by A. Kulesz; 2 by N. Stawarz).

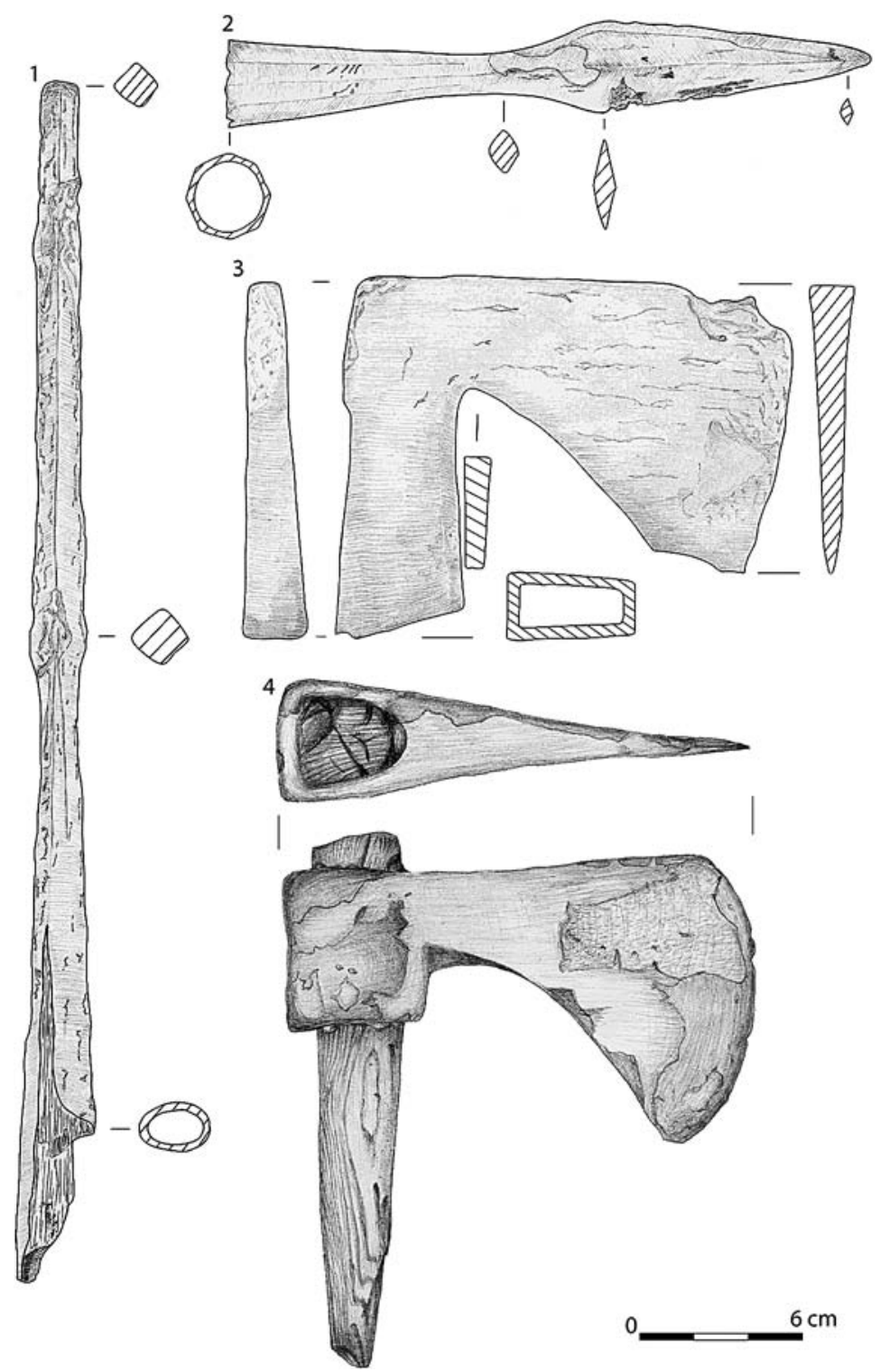

polygon. The transition to the head was quite smooth. Objects of this type with a polygonal sleeve appeared in the thirteenth century and were in use throughout the Late Middle Ages (Lech 2008, 88; Pydyn et al. 2018, 190).

The next artefact was significantly corroded and partially damaged; its total length was $43.8 \mathrm{~cm}$ (fig. 9: 1). It consists of two elements - a tip that gently widens and transitions into the sleeve, where a fragment of shaft was found. The tip had a $1.2 \times 1.2-\mathrm{cm}$ square cross-section. The tip transitioned into the sleeve by cutting. This object was found several metres north of the hypothetical axis of the bridge. Analysing the way the discussed 

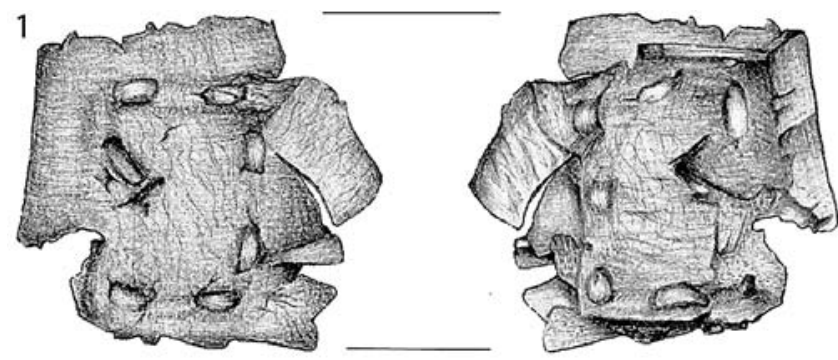

Fig. 10. Artefacts made of organic materials from the bridge to Ledniczka Island (1 by N. Stawarz; 2 by K. Radnicka; 3 by A. Kulesz; 4, 5, 6 by K. Kociszewska).
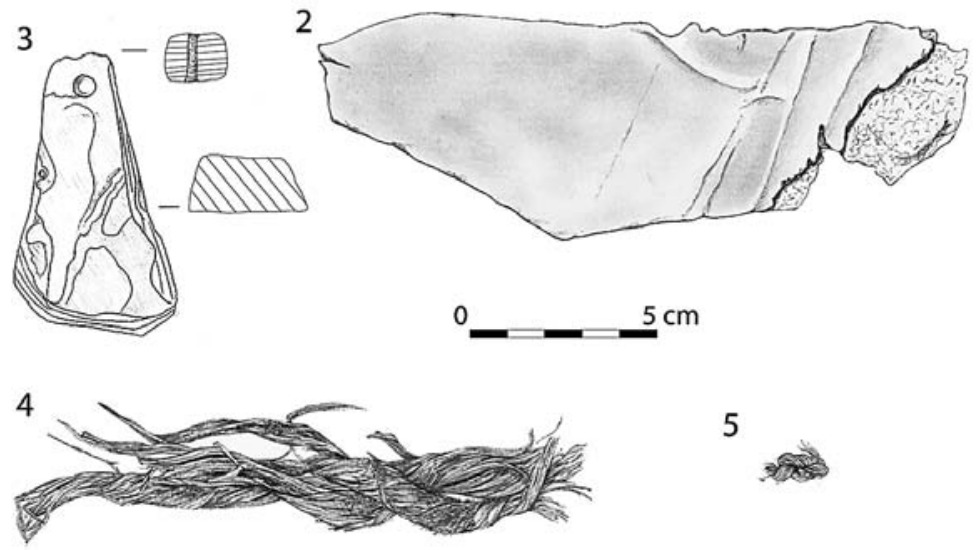

5

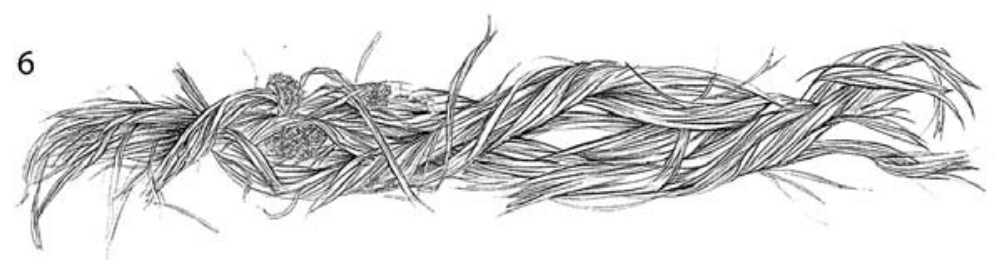

object was formed, it can be assumed that it is a pike head. This type of weapon was used in the fifteenth or sixteenth century (Lech 2008, 131-133; Pydyn et al. 2018, 191).

Another interesting category of artefacts is that of fishing-related objects. The first is a net float found between horizontal construction elements (fig. 10:3). This well-preserved item was made of bark and had a trapezoidal shape with its longest side being $7.8 \mathrm{~cm}$. At its narrowest part there was a hole with a diameter of $0.6 \mathrm{~cm}$, and on the edge of the shortest side there was an imprint - most probably from a string that had been threaded through the hole. By comparing the object to finds from Gdańsk, which comprise the best compiled collection, this float can be assigned to group B - trapezoidal floats. Their chronology is very wide and ranges from the tenth to the early-fourteenth century. Similar items have been found in most coastal sites, confirming their widespread nature (Rulewicz 1994, 172; Pydyn et al. 2018, 191-192). It should be noted that during the examination of the Gniezno bridge, five floats were found, four of which were made of bark (Szulta 2000, 109). Meanwhile, during the excavation of the Poznan bridge, four floats were found, three of which 
Fig. 11. Orthophotography of fish trap in situ (by P. Stencel).

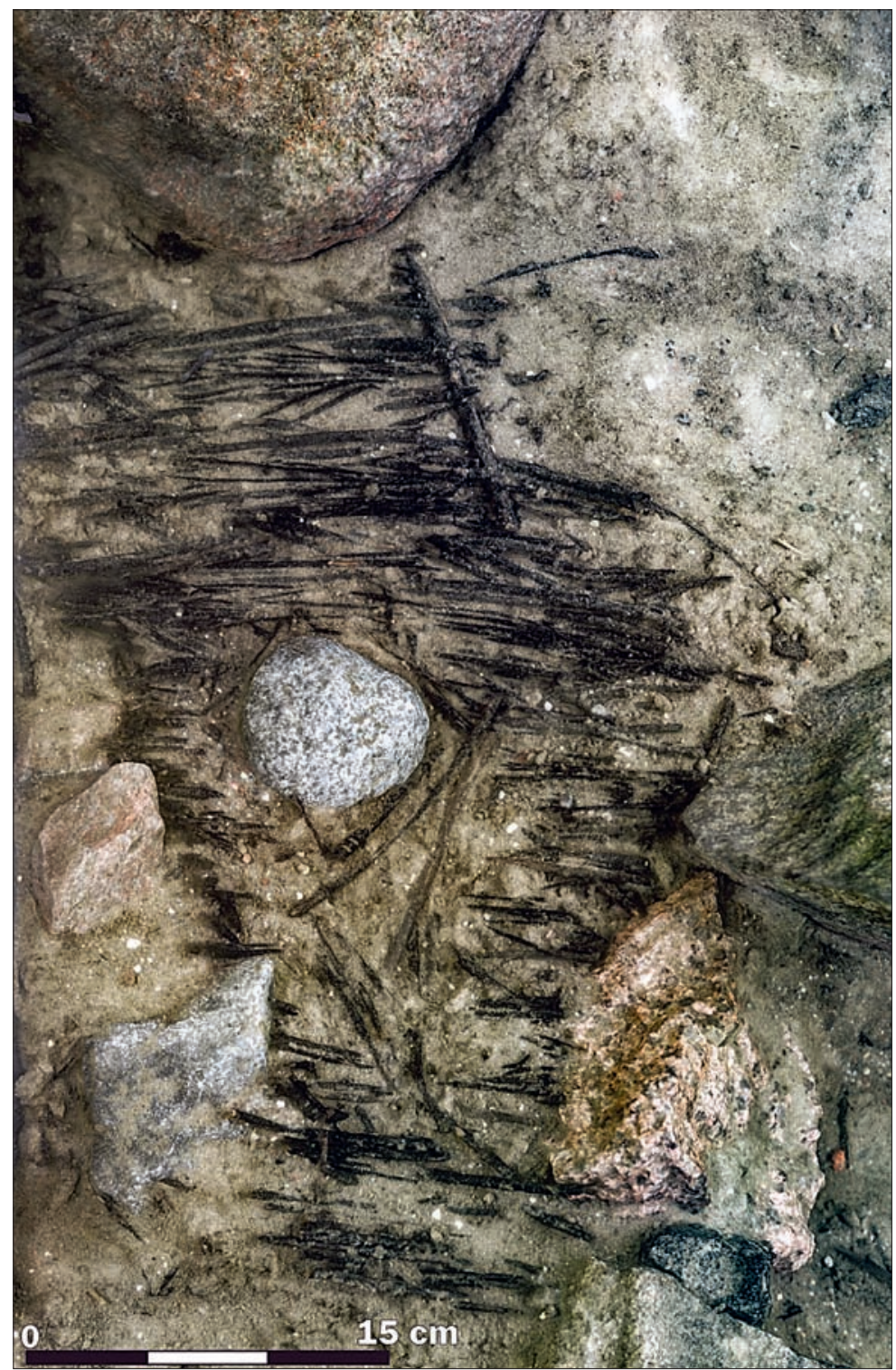

were made of bark. One of these specimens was similar in shape to the float found on the bridge to Ledniczka (Radka 2014b, 158).

The second fishing-related artefact in the area of the bridge crossing to Ledniczka is the remains of a woven basket containing a rock (fig. 11). Judging by the shape of the object and where it was found, it can be assumed that it was a fish trap basket. Fish trap baskets were made of willow, hazel or birch twigs. They varied in shape and size (Gręzak et al. 2018, 175). Medieval items of this type in Poland are known from four specimens. These were found at the following sites: Ostrówek in Opole (Hołubowicz 1955, 215, fig. 13), 
Gdańsk (Rulewicz 1994, 197), Nowy Dworek (Chudziak et al. 2016, 184, fig. 194) and the Poznań bridge on Lake Lednica (Gręzak et al. 2018). Only this last site has been subjected to radiocarbon analysis, which showed that it came from the twelfth to thirteenth century (Grezak et al. 2018, 175), i.e., from after the bridge had been destroyed.

As mentioned earlier, the anaerobic conditions found in bottom sediments are favourable for the preservation of organic material. In the immediate vicinity of the crossing to Ledniczka, two leather items and three fragments of rope were found. The first leather item had no distinctive features, whereas the second consisted of two pieces of tanned leather with a leather thong ( $f$ ig. 10: 1). The slightly ragged object resembled a $9 \times 10.5-\mathrm{cm}$ rectangle. There are seven pieces of leather cord on one side and six on the other. Such a shape and structure suggest that it may be a fragment of a poulaine (or "crakow") shoe. Similar items were found during the research on the Gniezno bridge (Drqżkowska 2000, 190). Another category of organic objects is rope fragments (fig. 10:4-6). Two are made of two strands, and one of the smallest is made of three strands. In the Middle Ages, cords and ropes were made of phloem, linen, hemp, hair and wool (Maik 1991, 21, 38). The current collection of ropes from the Ledniczka bridge is clearly less extensive than that found on the Gniezno bridge (Grupa 2000,142), but this is undoubtedly a function of the scale of the research that has been carried out.

\section{Conclusion}

The bridge to Ledniczka is one of the most important archaeological discoveries made in the waters of Lake Lednica in the last dozen or so years. The last three seasons of research made it possible to propose new research hypotheses and to find many interesting artefacts. At the present stage of research, we can say that Ledniczka Island was connected to the western shore of the lake by a bridge from early Piast times erected in the tenth century. ${ }^{2}$ It is not known when it ceased to be used, but it seems unlikely that it could have survived the Gniezno and Poznań bridges, the use of which ended during the crisis of the early Piast monarchy in the late 1030s. A new crossing to Ledniczka was built at the turn of the fourteenth century.

In light of dendrochronological dating and a number of radiocarbon dates, it is certain that in the tenth century a bridge was in operation here. The most intriguing question is whether it was created at a similar time as the Gniezno and Poznań crossings, or whether it is older. Answering this question is not made easier by the limited number of artefacts from the tenth century obtained during underwater research of the bridge. ${ }^{3}$ On Ledniczka Island itself, the tenth-century layers were also largely destroyed during major subsequent

\footnotetext{
2 The structure of the bridge to Ledniczka differs markedly from that of the bridges to Ostrów Lednicki. At this stage of the research, spatial analysis of the pile distribution does not allow for a clear identification of conformity with the construction of Slavic bridges in Polish lands and the Slavic Odra River region.

3 The lack of cultural objects dating from the first phase of the bridge can be explained by the brevity of the structure's operation and the limited size of the underwater area explored. Meanwhile, the thinness of the tenth to eleventh century layers on Ledniczka is probably explained by significant earthworks conducted there in the Late Middle Ages and by the state of progress of the research (since excavations have thus far covered only the motte-type structure).
} 
earthwork, and only limited archaeological research has been carried out here. It therefore seems justified to conduct another, comprehensive excavation on this island.

Another bridge to Ledniczka was built at the turn of the fourteenth century. At present, its functioning is confirmed by fewer dendrochronological and radiocarbon dates than for the tenth-century crossings. On the other hand, the vast majority of the artefacts acquired in the last three seasons of underwater research can be associated with the thirteenth/fourteenth-century phase of the operation of this crossing. Also, the general archaeological context - in the form of the identified motte-type residence dating back to the thirteenth to fifteenth century - would justify the erection of a bridge connecting Ledniczka with the mainland. The function of this stronghold has not been positively determined (Górecki et al. 1996, 197): it was certainly no longer a core of central power, but a seat of local authorities - perhaps of a castellan or a local noble family. Either while or after the crossing was in operation, there was fishing activity in this place, as evidenced by the find of a float and fish trap.

The three seasons of research on the relics of the bridge to Ledniczka provided extremely interesting results. They also allowed a number of new hypotheses and research questions to be formulated: the key question is what role Ledniczka Island's defensive structure and its bridges to the mainland played in the wider Ostrów Lednicki settlement complex.

\section{References}

Abramek, B. 2007: Studia z dziejów wojskowości, budownictwa, kultury. Muzeum Ziemi Wieluńskiej w Wieluniu - Militaria z grodziska średniowiecznego w Widoradzu pod Rudą koło Wielunia. Archaeologia Historica Polona 17, 95-111.

Banaszak, D. - Tabaka, A. 2016: Kompleks osadniczy i pozostałości działalności gospodarczej wczesnośredniowiecznego centrum. In: Kurnatowska - Wyrwa eds. 2016, 285-298.

Chudziak, W. - Kaźmierczak, R. - Niegowski, J. 2016: Podwodne dziedzictwo archeologiczne Polski. Katalog stanowisk (badania 2011-2015). Toruń: Wydawnictwo Fundacji Amicus Universitatis Nicolai Copernici - Wydawnictwo Uniwersytetu Mikołaja Kopernika.

Drażkowska, A. 2000: Wyroby skórzane. In: Kurnatowska ed. 2000, 189-200.

Duczko, W. 2016: Złoty młot boga Thora? O fragmencie skandynawskiej ozdoby z Ostrowa Lednickego. In: Kurnatowska - Wyrwa eds. 2016, 299-301.

Gedl, M. 2002: Pozostałości drewnianej budowli w średniowiecznym gródku w Zbrojewsku. Archaeologia Historica Polona 12, 73-80.

Głosek, M. 1996: Późnośredniowieczna broń obuchowa w zbiorach polskich. Warszawa - Łódź: Instytut Archeologii i Etnologii PAN.

Gtosek, M. - Kirpičnikov, A. N. 2000: Militaria - broń sieczna. In: Kurnatowska ed. 2000, 73-76.

Goslar, T. 2017: Raport z wykonania datowań C-14 w Poznańskim Laboratorium Radiowęglowym. Poznań: Poznańskie Laboratorium Radiowęglowe. Ms. dep. in the archive of the Uniwersytet Mikołaja Kopernika w Toruniu.

Goslar, T. 2018a: Raport z wykonania datowań C-14 w Poznańskim Laboratorium Radiowęglowym. Poznań: Poznańskie Laboratorium Radiowęglowe. Ms. dep. in the archive of the Uniwersytet Mikołaja Kopernika w Toruniu.

Goslar, T. 2018b: Raport z wykonania datowań C-14 w Poznańskim Laboratorium Radiowęglowym. Poznań: Poznańskie Laboratorium Radiowęglowe. Ms. dep. in the archive of the Uniwersytet Mikołaja Kopernika w Toruniu.

Górecki, J. 2016: Dzieje badań Ostrowa Lednickiego. In: Kurnatowska - Wyrwa eds. 2016, 29-44.

Górecki, J. - Łastowiecki, M. 2016: Konstrukcje obronne Ostrowa Lednickiego. In: Kurnatowska - Wyrwa eds. 2016, 59-72. 
Górecki, J. - Łastowiecki, M. - Wrzesiński, J. 1996: Gródek na Lednicze. Studia Lednickie IV, 197-246.

Gręzak, A. - Iwaszczuk, U. - Pydyn, A. - Popek, M. - Radka, K. 2018: Średniowieczna wiersza z rejonu mostu zachodniego na Ostrowie Lednickim. Studia Lednickie XVII, 161-179.

Grupa, M. 2000: Sprzęt i wyposażenie gospodarstwa domowego In: Kurnatowska ed. 2000, 139-163.

Hotubowicz, W. 1955: Prace wykopaliskowe na Ostrówku w Opolu w 1954 r. Sprawozdania Archeologiczne I, 207-219.

Kola, A. 2000: Archeologiczne badania podwodne na reliktach mostów. In: Kurnatowska ed. 2000, 11-28.

Kola, A. - Radka, K. - Wilke, G. 2016: Mosty traktu „poznańskiego" i „gnieźnieńskiego" w świetle badań podwodnych (1982-2015). In: Kurnatowska - Wyrwa eds. 2016, 107-130.

Kola, A. - Wilke, G. 1983: Wstępne sprawozdanie z archeologicznych badań podwodnych przeprowadzonych na reliktach mostów wczesnośredniowiecznych w Jeziorze Lednickim w latach 1982-1983. Toruń: Uniwersytet Mikołaja Kopernika w Toruniu. Ms. dep. in the archive of the Uniwersytet Mikołaja Kopernika w Toruniu.

Kola, A. - Wilke, G. 1989: Sprawozdanie z archeologicznych badań podwodnych reliktów wczesnośredniowiecznego mostu "poznańskiego" (Rybitwy, stan. 3a) w jeziorze Lednickim w latach 1986-1987. Studia Lednickie I, 77-97.

Kola, A. - Wilke, G. 2000: Mosty sprzed tysiąca lat. Toruń: Uniwersytet Mikołaja Kopernika w Toruniu.

Kola, A. - Wilke, G. eds. 2014: Wczesnośredniowieczne mosty przy Ostrowie Lednickim. Tom II. Mosty traktu poznańskiego (wyniki archeologicznych badań podwodnych prowadzonych w latach 1986-2003). Kraków: Towarzystwo Autorów i Wydawców Prac Naukowych „Universitas".

Kowalczyk, A. - Tabaka, A. - Miciak, M. 2019: Ранньосередньовічні пам'ятки руського походження з Острова Ледницького і Ґеча. Ucrainica Mediaevalia II, 83-108.

Krapiec, M. 2000: Badania dendrochronologiczne reliktów mostu "gnieźnieńskiego" w Jeziorze Lednickim. In: Kurnatowska ed. 2000, 49-56.

Kurnatowska, Z. ed. 2000: Wczesnośredniowieczne mosty przy Ostrowie Lednickim. Tom 1. Mosty traktu gnieźnieńskiego. Lednica - Toruń: Muzeum Pierwszych Piastów na Lednicy.

Kurnatowska, Z. - Wyrwa, A. M. eds. 2016: Ostrów Lednicki. Rezydencjonalo-stołeczny ośrodek pierwszych Piastów. Warszawa: Wydawnictwo Instytutu Archeologii i Etnologii PAN.

Lech, M. 2008: Broń biała na Śląsku w XIV-XVI wieku. Wratislavia Antiqua, Tom 10. Wrocław: Uniwersytet Wrocławski.

Leśny, J. 1976: Początki, rozwój i upadek kasztelani na Ostrowie Lednickim. Studia i Materiały do Dziejów Wielkopolski i Pomorza 12 (23), 5-37.

Maik, J. 1991: Tekstylia wczesnośredniowieczne z wykopalisk w Opolu. Warszawa - Łódź: Instytut Historii Kultury Materialnej PAN.

Mateuszewska-Kola, W. 2000: Przedmioty z poroża i kości. In: Kurnatowska ed. 2000, 201-208.

Nadolski, A. 1954: Studia nad uzbrojeniem polskim w X, XI i XII wieku. Acta Archaeologica Universitatis Lodziensis 3, 1-106.

Ossowski, W. 1999: Studia nad todziami jednopiennymi z obszaru Polski. Gdańsk: Wydawnictwo Marpress.

Ossowski, W. 2014: Łodzie jednopienne z Jeziora Lednickiego. In: Kola - Wilke eds. 2014, 249-258.

Popek, M. 2014: Militaria - broń miostająca. In: Kola - Wilke eds. 2014, 135-137.

Pydyn, A. 2018: Sprawozdanie z archeologicznych badań podwodnych przeprowadzonych na reliktach mostu na Ledniczkę (Rybitwy, stan. 28) oraz prospekcji podwodnych zrealizowanych w sąsiedztwie tej wyspy w dniach 04. 07 - 30. 07. 2018 roku. Ms. dep. in the archive of the Uniwersytet Mikołaja Kopernika w Toruniu.

Pydyn, A. - Popek, M. 2019: Sprawozdanie z archeologicznych badań podwodnych przeprowadzonych na reliktach mostu na Ledniczkę (Rybitwy, stan. 28) oraz wykopu sondażowego W3/2015 zlokalizowanego przy wyspie Ostrów Lednicki w dniach 01. 07 - 31. 07. 2019 roku. Ms. dep. in the archive of the Uniwersytet Mikołaja Kopernika w Toruniu.

Pydyn, A. - Popek, M. - Dębicka, D. - Radka, K. 2018: Przeprawa mostowa na wyspę Lednicza. Wstępne wyniki badań. Studia Lednickie XVII, 181-197.

Radka, K. 2014a: Analizy matematyczno-statystyczne materiału dendrochronologicznego mostów przy Ostrowie Lednickim. In: Kola - Wilke eds. 2014, 33-40.

Radka, K. 2014b: Narzędzia rolnicze i gospodarskie. In: Kola - Wilke eds. 2014, 153-176.

Radka, K. 2017: Trzecia łódź jednopienna z Ostrowa Lednickiego. Studia Lednickie XVI, 81-98.

Rodzińska-Choraży, T. 2016: Stan badań nad architekturą Ostrowa Lednickiego (1993-2015). In: Kurnatowska - Wyrwa eds. 2016, 143-172. 
Rulewicz, M. 1994: Rybołówstwo Gdańska na tle ośrodków miejskich Pomorza od IX do XIII wieku. Wrocław: Zakład Narodowy im. Ossolińskich.

Sankiewicz, P. 2011: Kolekcja mieczy w zbiorach Muzeum Pierwszych Piastów na Lednicy In. A. M. Wyrwa et al. eds., Miecze średniowieczne z Ostrowa Lednickiego i Giecza, Dziekanowice - Lednica: Muzeum Pierwszych Piastów na Lednicy, 13-18.

Sankiewicz, P. 2013: Kolekcja toporów ze zbiorów Muzeum Pierwszych Piastów na Lednicy In. P. Sankiewicz - A. M. Wyrwa eds., Topory średniowieczne z Ostrowa Lednickiego i Giecza, Lednica: Muzeum Pierwszych Piastów na Lednicy, 25-34.

Sankiewicz, P. 2018: Uzbrojenie ochronne i broń drzewcowa w zbiorach Muzeum Pierwszych Piastów na Lednicy In. P. Sankiewicz - A. M. Wyrwa eds., Broń drzewcowa i uzbrojenie ochronne z Ostrowa Lednickiego, Giecza i Grzybowa, Lednica: Muzeum Pierwszych Piastów na Lednicy, 27-32.

Sokotowski, M. 1876: Ruiny na Ostrowie jeziora Lednicy, studyjum nad budownictwem w przedchrześcijańskich wiekach w Polsce. Na podstawie badań wspólnie na miejscu odbytych z profesorem Władysławem Łuszczkiewiczem. Pamiętnik Akademii Umiejętności w Krakowie, wydziały filologiczny i historyczno filologiczny 3. Kraków.

Szulta, W. 2000: Narzędzia rolnicze i gospodarskie. In: Kurnatowska ed. 2000, 105-137.

Szulta, W. 2008: Przeprawy mostowe na ziemiach polskich w średniowieczu. Toruń: Towarzystwo Naukowe w Toruniu.

Tokarski, M. 2000: Militaria - broń miotająca, obuchowa i drzewcowa oraz elementy rzędu końskiego i oporządzenia jeździeckiego. In: Kurnatowska ed. 2000, 77-104.

Wachowski, K. 1982: Średniowieczna broń na Śląsku w świetle znalezisk z Ostrówka w Opolu. Archeologia Polski 27, 186-192.

Wasilewski, T. 1967: Ostrów Lednicki. In: Słownik Starożytności Słowiańskich 3, Wrocław: Zakład Narodowy im. Ossolińskich, 554.

Ważny, T. 2017: Analiza dendrochronologiczna próbek drewna z archeologicznych badań podwodnych w jeziorze Lednica (2017 r. Ms. dep. in the archive of the Uniwersytet Mikołaja Kopernika w Toruniu.

Ważny, T. 2019: Analiza dendrochronologiczna próbek drewna z archeologicznych badań podwodnych w Jeziorze Lednickim (2019 r.). Ms. dep. in the archive of the Uniwersytet Mikołaja Kopernika w Toruniu.

Wilke, G. 2000: Analiza przestrzenno-chronologiczna struktur palowych i próba rekonstrukcji mostów. In: Kurnatowska ed. 2000, 57-72.

Wilke, G. 2006: Próba interpretacji podwodnych odkryć militariów przy rezydencji pierwszych Piastów na Ostrowie Lednickim. In: M. Dworaczyk et al. eds., Świat Słowian wczesnego średniowiecza, Szczecin Wrocław: Wydawnictwo Instytutu Archeologii i Etnologii PAN, 443-455.

Wilke, G. 2014: Analiza chronologiczno-przestrzenna struktur palowych reliktów mostu "poznańskiego" i próba jego rekonstrukcji. In: Kola - Wilke eds. 2014, 41-68.

Wrzesiński, J. - Kara, M. 2016: Chronologia i fazy użytkowania tzw. II kościoła na Ostrowie Lednickim. In: Kurnatowska - Wyrwa eds. 2016, 173-193.

Wyrwa, A. 2016: Podsumowanie. In: Kurnatowska - Wyrwa eds. 2016, 303-304.

ANDRZEJ PYDYN, Centre for Underwater Archaeology, Nicolaus Copernicus University in Torun, Szosa Bydgoska 44/48, PL-87 100 Toruń; pydyn@umk.pl

MATEUSZ POPEK, Centre for Underwater Archaeology, Nicolaus Copernicus University in Torun, Szosa Bydgoska 44/48, PL-87 100 Toruń; mpopek@umk.pl 